\title{
АВТОМАТИЗОВАНА ЕКСПЕРТНА СИСТЕМА ОЦІНЮВАННЯ РЕЗУЛЬТАТІВ ОБСТЕЖЕННЯ МОЛОЧНИХ ЗАЛОЗ ДЛЯ КОНТАКТНОЇ ЦИФРОВОЇ ТЕРМОГРАФІї
}

\author{
В. О. Білошенко, В. Г. Гур'янов ${ }^{1}$, Ю. Є. Лях², В. В. Приходченко \\ Донецький фрізико-технічний інститут ім. О. О. Галкіна НАН України \\ ${ }^{1}$ Національний медичний університет імені О. О. Богомольця \\ ${ }^{2}$ Східноєвропейський національний університет імені Лесі Українки
}

\begin{abstract}
Проблеми ранньої діагностики раку молочної залози пов'язані з якістю та тривалістю життя жінок. Одним із шляхів вирішення цієї проблеми є проведення скринінгу — профілактичного обстеження жінок, починаючи з 35-річного віку.

Контактна цифрова термографрія молочних залоз відповідає вимогам для первинного обстеження молочних залоз, проте оцінювання результатів термограсрії потребує підготовки кваліфрікованих спеціалістів.

Вирішення проблеми спрощення та прискорення оцінювання результатів термограсрії може бути здійснено за рахунок розроблення програмного комплексу для автоматизованого оцінювання термограм.

Проведено аналіз 685 записів термограм жінок, віком від 18 до 86 років, яким за результатом комплексного обстеження був виставлений кінцевий діагноз. Для оцінювання розподілу поля температур молочних залоз використано алгоритм оцінювання показника Херста для фрракталів високої розмірності.

При проведенні статистичного аналізу виявлено інформативні показники, що описують поле температур молочних залоз, які дозволяють провести дискримінацію норми та патології. На виділених ознаках побудована математична модель прогнозування ризику патології молочних залоз. Автоматизована система аналізу реалізована в нелінійних нейромережевих моделях, що дозволило з 90,2 \% чутливістю та 85,1 \% специфічністю прогнозувати ризик патології.

Отже, розроблено автоматизовану систему, що дозволяє з використанням методу термограсрії виявляти патологію молочних залоз при проведенні скринінгових досліджень підготовленим медичним працівником із сестринською або фрельдшерською освітою, сімейним лікарем.
\end{abstract}

Ключові слова: захворювання молочних залоз, термографрія, фррактальний аналіз, модель прогнозування.

\section{AUTOMATED SYSTEM FOR EVALUATION OF THE MAMMARY GLANDS EXAMINATION RESULTS FOR CONTACT DIGITAL THERMOGRAPHY}

\author{
V. O. Biloshenko, V. G. Gurianov1, Yu. Ye. Liakh², V. V. Pryhodchenko \\ Donetsk institute for physics and engineering named after O. O. Galkin of NAS of Ukraine \\ ${ }^{1}$ Bogomolets National Medical University \\ ${ }^{2}$ Lesya Ukrainka Eastern European National University
}

\begin{abstract}
Background. The problems of early diagnosis of breast cancer are related to the quality and life expectancy of women. One of the ways to solve this problem is to conduct screening - a preventive examination of women, starting from 35 years.

The contact digital thermography of the mammary glands meets the requirements for the primary examination of the mammary gland, but evaluation of the results of thermography requires the training of qualified specialists.

Purpose. Solving the problem of simplifying and accelerating the evaluation of the results of thermography data can be accomplished by developing a software package for the automated evaluation of thermograms.

Materials and methods. 685 records of thermograms of women aged 18-86 years, which have the final diagnosis based on a comprehensive examination was analyzed. To estimate the distribution of the temperature of the mammary glands, an algorithm for estimating the Hurst index for the high dimensional fractals was used.

Results. By the statistical analysis, significant indicators describing the field of temperature of the mammary glands, which allow discriminating the norm and pathology, were revealed. On the significant variables, a mathematical model of prediction of the risk of breast pathology was constructed. The automated system was implemented by mean of nonlinear neural network models, which allows $90.2 \%$ sensitivity and $85.1 \%$ specificity to predict the risk of pathology.

Conclusion. The automated system is developed that allows using the thermography method to detect breast pathology during screening studies by a trained medical professional with nursing or paramedic education or family doctors.
\end{abstract}

Key words: mammary gland diseases, thermography, fractal analysis, neural model. 


\title{
АВТОМАТИЗИРОВАННАЯ ЭКСПЕРТНАЯ СИСТЕМА ОЦЕНКИ РЕЗУЛЬТАТОВ ОБСЛЕДОВАНИЯ МОЛОЧНЫХ ЖЕЛЕЗ ДЛЯ КОНТАКТНОЙ ЦИФРОВОЙ ТЕРМОГРАФИИ
}

\author{
В. А. Белошенко, В. Г. Гурьянов ${ }^{1}$, Ю. Е. Лях ${ }^{2}$ В. В. Приходченко \\ Донецкий фризико-технический институт им. А. А. Галкина НАН Украины \\ ${ }^{1}$ Национальный медицинский университет имени А. А. Богомольца \\ ${ }^{2}$ Восточноевропейский национальный университет имени Леси Украинки
}

Проблемы ранней диагностики рака молочной железы связаны с качеством и продолжительностью жизни женщин. Одним из путей решения этой проблемы является проведение скрининга — профилактического обследования женщин, начиная с 35-летнего возраста.

Контактная цисрровая термограсрия молочных желез отвечает требованиям первичного обследования молочных желез, однако оценка результатов термограсиии требует подготовки квалифицированных специалистов.

Цель. Решение проблемы упрощения и ускорения оценки результатов термограсии может быть осуществлено за счет разработки программного комплекса для автоматизированной оценки термограмм.

Материалы и методы. Проведен анализ 685 записей термограмм женщин в возрасте от 18 до 86 лет, которым по результатам комплексного обследования был выставлен окончательный диагноз. Для оценки распределения поля температур молочных желез использован алгоритм оценки показателя Херста для срракталов высокой размерности.

Результаты. При проведении статистического анализа выявлены информативные показатели, описывающие поле температур молочных желез, которые позволяют провести дискриминацию нормы и патологии. На выделенных признаках построена математическая модель прогнозирования риска патологии молочных желез. Автоматизированная система анализа реализована в нелинейных нейросетевых моделях, что позволило с 90,2% чувствительностью и 85,1 \% специфичностью прогнозировать риск патологии.

Выводы. Разработана автоматизированная система, позволяющая с использованием метода термографии выявлять патологию молочных желез при проведении скрининговых исследований подготовленным медицинским работником с сестринским или фельдшерским образованием или семейным врачом.

Ключевые слова: заболевания молочних желез, термографрия, фррактальный анализ, модель прогнозирования. 
Вступ. Проблема раннього виявлення патології молочних залоз (МЗ), насамперед раку молочної залози (РМЗ), є однією з найбільш актуальних, оскільки РМЗ за даними канцер-реєстру України вже багато років впевнено посідає перше місце серед онкозахворювань жінок. Відкриття нових онкологічних центрів, укомплектування їх найсучаснішим і коштовним обладнанням є, безсумнівно, потрібною та дуже важливою діяльністю. Але цей шлях не вирішує всіх проблем онкології. Необхідно забезпечити можливість ранньої діагностики та відбору груп ризику в закладах первинної медичної допомоги, куди звертається основна маса населення. Для цього потрібна велика кількість відносно простих і дешевих приладів, здатних відокремити нормальний стан організму від стану, що несе ризик виникнення пухлини. Одним із перспективних методів регулярного обстеження численного контингенту населення є термографія [1-7].

Відомо, що структурним змінам в організмі людини передують зміни термопатофізіологічні - зростання температури як наслідок підвищеного метаболізму в тому місці, де пізніше може 3’явитись пухлина [8, 9]. Такі термофункціональні зміни часто випереджають структурні на декілька років. Саме ця обставина, що принципово відрізняє термографію від інших розповсюджених діагностичних засобів, робить її вельми корисною для раннього виявлення як пухлин, так і передумов до їх з’явлення, доповнює традиційні методи рентгенографії та ультразвукової діагностики. Неінвазивність та безпечність для здоров'я пацієнтів при використанні термографії, ефективність визначення патологічних змін у МЗ з наступним встановленням кінцевого діагнозу за результатами клінічних обстежень дозволяють вважати цей метод доцільним для широкого застосування [1, $2,10,11]$.

Термографічні методи підрозділяються на дистанційні та контактні [2, 4, 12]. Серед дистанційних методів найбільше розповсюдження має інфрачервоне теплобачення $[12,13]$. Однак йому притаманні певні недоліки, що обмежують використання такої термодіагностики в медичних закладах первинної мережі [4]. Контактна термографія, що базується на мікропроцесорних системах одержання й оброблення інформації, проста в експлуатації, мобільна, дешева та дозволяє організувати масове обстеження населення навіть за межами стаціонарної медичної установи. Спеціалістами Донецького фізико-технічного інституту ім. О. О. Галкіна НАН України спільно з медиками розроблено термограф контактний цифровий ТКЦ-1 [4, 14] — сучасний медичний прилад, що серійно виробляється ТОВ «НВП «Метекол», м. Ніжин, і внесений до Державного реєстру медичної техніки та виробів медичного призначення України, дозволених для застосування в медичній практиці. Він використовується в закладах охорони здоров’я майже всіх регіонів України насамперед для ранньої діагностики пухлинних захворювань М3 з метою виявлення груп ризику, контролю розвитку хвороби та ії лікування.

Аналіз поля температур МЗ на термограмах, отриманих із застосуванням ТКЦ-1, свідчить про наявність відмінностей для норми $(\mathrm{H})$ та патології (П). При цьому важливою характеристикою є площа області підвищених температур і асиметрія розподілу температури між правою та лівою М3 у симетричних точках вимірювання DeltT = |ТліваТправа|. Програмне забезпечення термографа передбачає можливість проведення кількісного аналізу площі підвищеної температури МЗ, гістограми розподілу підвищення температурного поля, асиметрії розподілу температур правої і лівої МЗ.

Ефективним інструментом кількісного аналізу складних медичних зображень з метою діагностики є методи фрактального аналізу [15, 16]. В роботах [17-20] вони використовуються для розпізнавання патологічних процесів у M3 із даних термографії. Автори [17] виділяють ділянки поверхні з найбільшою температурою й аналізують контури виділених ділянок, розраховуючи їх фрактальну розмірність. Показано, що в разі доброякісної пухлини її фрактальна розмірність складає

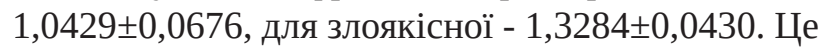
вказує на те, що контури злоякісної пухлини більш іррегулярні, ніж доброякісної. Злоякісне новоутворення часто характеризується як хаотичне, слабо регульоване, погано описується евклідовою геометрією [18]. Для класифікації мамографічних зображень доброякісної і злоякісної пухлин використовується Multifractal spectrum [19]. У роботі [20] встановлено відмінність показника Херста двовимірного поля температур у випадках Н та П.

Незважаючи на те, що кількісна оцінка термограм, отриманих методом контактної термографії, дозволяє доволі детально характеризувати поле температур для Н та П, якісна термографічна діагностика захворювань МЗ потребує втручання кваліфікованого фахівця з термографії, що унеможливлює обстеження великої кількості пацієнтів, 
віддалених від медичних центрів, зокрема, численного контингенту сільських місцевостей.

Мета роботи: підвищити ефективність виявлення жінок із патологією МЗ при профілактичних оглядах із застосуванням контактної цифрової термографії, а саме, термографа ТКЦ-1. Для цього в роботі поставлено такі завдання: 1 . На підставі даних попереднього комплексного обстеження М3 жінок із встановленою патологією виявити найбільш вірогідні кількісні показники термограм, що відрізняють наявність патології або її відсутність. Визначити чутливість та специфічність виявлених ознак. 2. Із врахуванням найбільш вірогідних для виявлення патології М3 температурних показників розробити автоматизовану систему експертної оцінки термограм для формування груп жінок із патологією та без патології МЗ.

Матеріал і методи дослідження. В роботі використані дані термограм М3 685 жінок, які попередньо комплексно обстежені. Обстеження включало: огляд мамолога, термографію (термограф ТКЦ-1), рентгеномамографію (мамограф «Мадіс», «Радмір»), ультразвукову діагностику (цифровий доплерівський ультразвуковий комплекс ULTIMA Pro-30, «Радмір»), аспіраційну та трепан-біопсію за цитологічним і гістологічним дослідженнями. Обстеження проводилось протягом 2014-2018 років. Вік жінок становив від 18 до 86 років. У 399 (45,1 \%) жінок патології М3 не виявлено, у 376 (54,9 \%) підтверджені патологічні процеси. Серед них: кісти (К) - у 16, фіброаденоми (ФА) - у 19, фіброзно-кістозної мастопатії (ФКМ) — у 143, РМ3 - у 198 жінок. Отримані для проведення аналізу термограми представляли собою двовимірне поле розподілу температур поверхні М3, окремий датчик видавав усереднене значення температури поверхні площею 1х1 см2. На рис. 1 наведено приклади розподілу поля температур М3, отриманих за допомогою термографа ТКЦ-1.

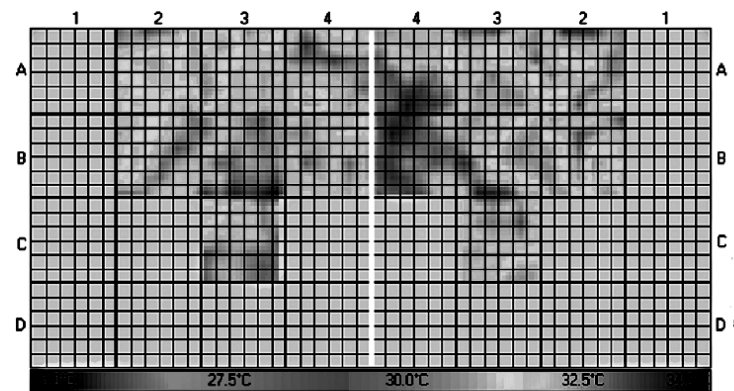

a)

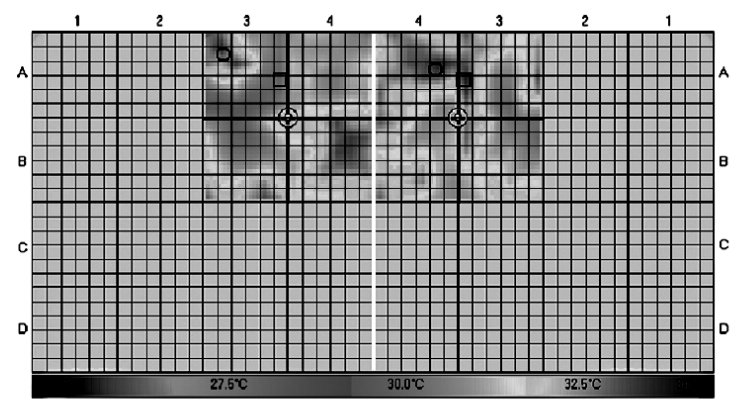

B)

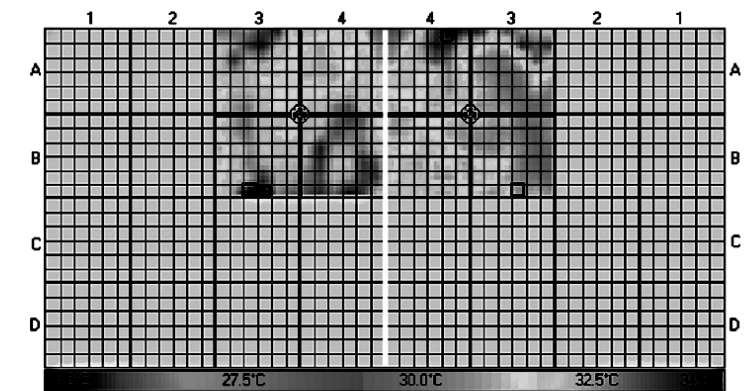

б)

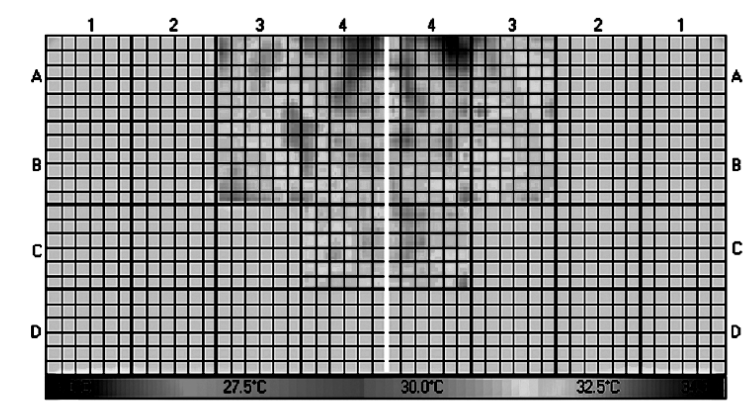

г)

Рис. 1. Варіанти розподілу поля температур М3, отримані за допомогою термографа ТКЦ-1: а) Н; б) рак лівої МЗ; в) ФА правої МЗ; г) двостороння ФКМ

Для оцінювання структури поля температур використано алгоритм оцінки показника Херста для фракталів високої розмірності [20, 21]. В цьому випадку для двовимірного простору поля температур проводиться розбиття його на домени $\mathrm{d}$ розміром $\mathrm{n}_{1} \mathrm{xn}_{2}$. Для кожного розміру домену методом Detrending Moving Average analysis
(DMA) розраховується показник узагальненої дисперсії $\sigma_{D h A}^{2}$, значення якого залежить від розміру домену:

$$
\sigma_{D M A}^{2}\left(n_{1}, n_{2}\right) \sim\left[\sqrt{n_{1}^{2}+n_{2}^{2}}\right]^{2 \text { Hrrst }},
$$


де $\sigma_{D M A}\left(n_{1}, n_{2}\right)$ - узагальнене стандартне відхилення, розраховане для домена розміру $\mathrm{n}_{1} \mathrm{xn}_{2}$, Herst - значення показника Херста поля розподілу температур. Розрахунки проводилися для квадратів $\mathrm{n}_{1}=\mathrm{n}_{2}=\mathrm{n}$, у якості характеристики поля температур були розраховані логарифми показника узагальненої дисперсії для квадратів розміром від 2х2 до 12x12.

В якості ознак, що оцінюють термограму, було проаналізовано 68 показників. До них включено три показники загальної характеристики: вік пацієнтки (Age), мінімальна температура поля М3 (використана 0,5 \% перцентіль значень поля температур - Tрегс005), розмір поля температур М3 $\left(\mathrm{N}, \mathrm{cm}^{2}\right)$. Крім того, 32 показники відносної площі підвищення температур М3 (табл. 1) та 33 показники характеристики термограм МЗ за алгоритмом оцінки показника Херста для фракталів високої розмірності (табл. 2).

Таблиця 1

\section{Показники оцінювання поля температур молочних залоз}

\begin{tabular}{|c|c|c|c|}
\hline \multicolumn{2}{|c|}{$\begin{array}{c}\text { Відносна площа підвищення } \\
\text { (у порівнянні з Треrс005) температур МЗ }\end{array}$} & \multicolumn{2}{|c|}{$\begin{array}{c}\text { Відносна площа асиметрії } \\
\text { поля температур МЗ }\end{array}$} \\
\hline Показник & Діапазон температур & Показник & Діапазон температур \\
\hline$<0,2$ & на $0-0,2^{0} \mathrm{C}$ & $\operatorname{Delt}(<0,2)$ & на $0-0,2^{0} \mathrm{C}$ \\
\hline $0,2-0,4$ & на $0,2-0,4^{0} \mathrm{C}$ & $\operatorname{Delt}(0,2-0,4)$ & на $0,2-0,4^{0} \mathrm{C}$ \\
\hline $0,4-0,6$ & на $0,4-0,6^{0} \mathrm{C}$ & $\operatorname{Delt}(0,4-0,6)$ & на $0,4-0,6^{0} \mathrm{C}$ \\
\hline $0,6-0,8$ & на $0,6-0,8^{0} \mathrm{C}$ & $\operatorname{Delt}(0,6-0,8)$ & на $0,6-0,8^{0} \mathrm{C}$ \\
\hline $0,8-1,0$ & на $0,8-1,0^{0} \mathrm{C}$ & $\operatorname{Delt}(0,8-1,0)$ & на $0,8-1,0^{0} \mathrm{C}$ \\
\hline $1,0-1,2$ & на $1,0-1,2^{\circ} \mathrm{C}$ & Delt(1,0-1,2) & на $1,0-1,2^{0} \mathrm{C}$ \\
\hline $1,2-1,4$ & на $1,2-1,4^{0} \mathrm{C}$ & Delt $(1,2-1,4)$ & на $1,2-1,4^{0} \mathrm{C}$ \\
\hline $1,4-1,6$ & на $1,4-1,6^{0} \mathrm{C}$ & $\operatorname{Delt}(1,4-1,6)$ & на $1,4-1,6^{0} \mathrm{C}$ \\
\hline $1,6-1,8$ & на $1,6-1,8^{0} \mathrm{C}$ & Delt(1,6-1,8) & на $1,6-1,8^{0} \mathrm{C}$ \\
\hline $1,8-2,0$ & на $1,8-2,0^{0} \mathrm{C}$ & Delt(1,8-2,0) & на $1,8-2,0^{\circ} \mathrm{C}$ \\
\hline $2,0-2,2$ & на $2,0-2,2^{0} \mathrm{C}$ & $\operatorname{Delt}(2,0-2,2)$ & на $2,0-2,2^{0} \mathrm{C}$ \\
\hline $2,2-2,4$ & на $2,2-2,4^{0} \mathrm{C}$ & $\operatorname{Delt}(2,2-2,4)$ & на $2,2-2,4^{0} \mathrm{C}$ \\
\hline $2,4-2,6$ & на $2,4-2,6^{0} \mathrm{C}$ & $\operatorname{Delt}(2,4-2,6)$ & на $2,4-2,6^{0} \mathrm{C}$ \\
\hline $2,6-2,8$ & на $2,6-2,8^{0} \mathrm{C}$ & $\operatorname{Delt}(2,6-2,8)$ & на $2,6-2,8^{0} \mathrm{C}$ \\
\hline $2,8-3,0$ & на $2,8-3,0^{0} \mathrm{C}$ & $\operatorname{Delt}(2,8-3,0)$ & на $2,8-3,0^{0} \mathrm{C}$ \\
\hline$>3,0$ & більше $3^{0} \mathrm{C}$ & $\operatorname{Delt}(>3,0)$ & більше $3^{0} \mathrm{C}$ \\
\hline
\end{tabular}

Таблиця 2

Характеристика термограм МЗ за алгоритмом оцінки показника Херста

\begin{tabular}{|c|c|c|c|}
\hline \multicolumn{2}{|c|}{$\begin{array}{c}\text { Узагальнене стандартне відхилення } \\
\text { для правої (R) та лівої (L) M3 }\end{array}$} & \multicolumn{2}{|c|}{$\begin{array}{c}\text { Узагальнене стандартне відхилення поля } \\
\text { асиметрії температур }\end{array}$} \\
\hline Показник & Розмір квадрату аналізу & Показник & Розмір квадрату аналізу \\
\hline Rln_S2 & $2 \times 2$ & R_L_ln_S2 & $2 \times 2$ \\
\hline Rln_S3 & $3 \times 3$ & R_L_ln_S3 & $3 \times 3$ \\
\hline Rln_S4 & $4 \times 4$ & R_L_ln_S4 & $4 \times 4$ \\
\hline Rln_S5 & $5 \times 5$ & R_L_ln_S5 & $5 \times 5$ \\
\hline Rln_S6 & $6 \times 6$ & R_L_ln_S6 & $6 \times 6$ \\
\hline Rln_S7 & $7 \times 7$ & R_L_ln_S7 & $7 \times 7$ \\
\hline Rln_S8 & $8 \times 8$ & R_L_ln_S8 & $8 \times 8$ \\
\hline Rln_S9 & $9 \times 9$ & R_L_ln_S9 & $9 \times 9$ \\
\hline
\end{tabular}


Характеристика термограм МЗ за алгоритмом оцінки показника Херста

\begin{tabular}{|c|c|c|c|}
\hline \multicolumn{2}{|c|}{$\begin{array}{c}\text { Узагальнене стандартне відхилення } \\
\text { для правої (R) та лівої (L) M3 }\end{array}$} & \multicolumn{2}{|c|}{$\begin{array}{c}\text { Узагальнене стандартне відхилення поля } \\
\text { асиметрії температур }\end{array}$} \\
\hline Показник & Розмір квадрату аналізу & Показник & Розмір квадрату аналізу \\
\hline Rln_S10 & $10 \times 10$ & R_L_ln_S10 & $10 \times 10$ \\
\hline Rln_S11 & $11 \times 11$ & R_L_ln_S11 & $11 \times 11$ \\
\hline Rln_S12 & $12 \times 12$ & R_L_ln_S12 & $12 \times 12$ \\
\hline L_ln_S2 & $2 \times 2$ & & \\
\hline L_ln_S3 & $3 \times 3$ & & \\
\hline L_ln_S4 & $4 \times 4$ & & \\
\hline L_ln_S5 & $5 \times 5$ & & \\
\hline L_ln_S6 & $6 \times 6$ & & \\
\hline L_ln_S7 & $7 \times 7$ & & \\
\hline L_ln_S8 & $8 \times 8$ & & \\
\hline L_ln_S9 & $9 \times 9$ & & \\
\hline L_ln_S10 & $10 \times 10$ & & \\
\hline L_ln_S11 & $11 \times 11$ & & \\
\hline L_ln_S12 & $12 \times 12$ & & \\
\hline
\end{tabular}

Для аналізу розподілу поля температур М3 та виявлення ознак термограм, пов'язаних із ризиком патології, застосовувалися методи статистичного аналізу [22-24]. Використовувався однофакторний дисперсійний аналіз (ANOVA та його непараметричний аналог), постеріорні порівняння проводилися за критерієм Шеффе або критерієм Данна у випадку закону розподілу, відмінного від нормального. Для побудови моделей прогнозування ризику патологічного процесу за виділеними значимими ознаками використано метод побудови та аналізу штучних нейромережевих моделей (у тому числі генетичні алгоритми відбору) [25]. Для оцінювання прогностичності факторних ознак при розділенні варіантів $\mathrm{H}$ та П використано методи побудови й аналізу кривих операційних характеристик (ROC curve).

Статистичний аналіз проводився за допомогою пакетів MedCalc v.18.11.3 (MedCalc Software bvba, 1993-2018) та EZR v.1.36 (Saitama Medical Center, Jichi Medical University), що є графічним інтерфейсом користувача для R (The R Foundation for Statistical Computing). Побудова та аналіз нейромережевих моделей виконувались у пакеті Statistica Neural Networks v. 4.0C (StatSoftInc., 1996-1999).

Результати та їх обговорення. Аналіз результатів кількісних показників термограм МЗ У результаті аналізу показників загальної характеристики було встановлено, що у пацієнток із
РМЗ та ФА середній вік зсунутий у більш старшу вікову категорію, ніж у нормі $(\mathrm{p}<0,05)$. Розмір М3 для жінок із патологічними процесами (РМЗ, ФКМ, ФА) також у середньому (медіанне значення 360 $\mathrm{cm}^{2}, 396$ см² $^{2}$ та 360 см² відповідно) вище $(\mathrm{p}<0,05)$, ніж у нормі (медіанне значення $288 \mathrm{~cm}^{2}$ ). Показник реперної температури МЗ для термограм Н не відрізняється від середнього значення при РМЗ ( $>>0,05)$.

Порівняння показників відносної площі підвищення температури МЗ для Н та П процесів для діапазону невеликого $\left(0^{\circ} \mathrm{C}-1,2^{\circ} \mathrm{C}\right)$ підвищення показало, що площі на термограмі норми були більшими $(\mathrm{p}<0,05)$, ніж для РМЗ та ФКМ. Особливо велика відмінність спостерігається для показника площі діапазону $\left(0,8^{\circ} \mathrm{C}-1,0^{\circ} \mathrm{C}\right)$, де медіанне значення для норми складає 12,5 \% загальної площі М3, а для П процесів — від 8 \% до 9 \%. У той же час при аналізі квартильних розподілів показників встановлено, що ні один із них окремо не може бути використаним у якості тесту для розділення Н та П процесів (не вдається указати порогове значення показника, що ефективно розділить Н від П).

Показники відносної площі підвищення температури М3 для середнього діапазону $\left(1,2^{\circ} \mathrm{C}-2,0^{\circ} \mathrm{C}\right)$ у випадку норми були меншими ( $<<0,05)$, ніж для РМЗ та ФКМ, а починаючи з діапазону $\left(2,4^{\circ} \mathrm{C}-2,6^{\circ} \mathrm{C}\right)$, і в порівнянні з ФА. Найбільш яскраво ця відмінність 
проявляється у показника площі діапазону $\left(2,6^{0} \mathrm{C}\right.$ $\left.-3,0^{\circ} \mathrm{C}\right)$, де медіанне значення для норми складає 0,3 \% загальної площі М3, а для процесів патології приблизно 3 \%. У разі діапазону (більше 3,00) для показника норми навіть значення третього квартилю склало 1,8 \%, при тому, що медіанне значення для груп РМЗ, ФКМ, ФА та К дорівнює 3,9 \%, 4,2 \%, 4,5\% та 3,1 \% відповідно. Отже, цей показник можна розглядати як інструмент розділення Н та П процесів. Однак ROC-аналіз вказує на те, що при виборі оптимального порогу розділення (П прогнозується при площі (більше 3,00) > 0,79 \%) чутливість і специфічність тесту не перевищують 70 \%. Тобто цей фактор не може бути використаний як єдина ознака для розділення Н та П процесів, а потребує додаткового підтвердження.

При порівнянні показників асиметрії розподілу температур правої та лівої МЗ встановлено таке. Для показників відносної площі асиметрії температур М3 діапазону $\left(0^{\circ} \mathrm{C}-0,6^{\circ} \mathrm{C}\right)$ у випадку норми показник невеликої асиметрії температур суттєво вище $(\mathrm{p}<0,05)$, ніж для процесів патології. Це дозволяє рекомендувати показник $\operatorname{Delt}(<0,2)$ як інструмент розділення Н та П процесів. При виборі оптимального порогу розділення методом аналізу кривих операційних характеристик (П прогнозується при площі $\operatorname{Delt}(<0,2)<19,8$ \%) отримані чутливість та специфічність тесту не перевищують 70 \%, і даний фактор не може бути використаний як єдина ознака для розділення вказаних процесів.

Для більших значень показників асиметрії розподілу поля температур лівої та правої МЗ виявлено перехід від більш високих показників площі для термограм норми (у діапазоні температур 0,60 $\left.0,8^{0} \mathrm{C}\right)$, ніж для патології ( $\left.\mathrm{p}<0,05\right)$, до більш високих показників площі для термограм патології $\left(1,0^{\circ} \mathrm{C}\right.$ $\left.-1,2^{\circ} \mathrm{C}\right)$, ніж для норми ( $\left.<0,05\right)$. Для середнього ж діапазону асиметрії поля температур $\left(0,8^{\circ} \mathrm{C}-1,0^{\circ} \mathrm{C}\right)$ розподіли майже співпадають, хоча відмінність $\mathrm{H}$ від ФКМ є статистично значимою $(\mathrm{p}<0,05)$.
У випадку значної $\left(>1,2^{\circ} \mathrm{C}\right)$ асиметрії поля температур спостерігається суттєва відмінність $(\mathrm{p}<0,05)$ показників. Так, для діапазону $\left(1,2^{\circ} \mathrm{C}\right.$ $-1,4^{0} \mathrm{C}$ ) медіанне значення площі у випадку $\mathrm{H}$ складає 3,5 \%, а для процесів П - 6 \% - 6,4 \% $(\mathrm{p}<0,05)$. Така відмінність характерна для всього діапазону значної $\left(>1,2^{\circ} \mathrm{C}\right)$ асиметрії температур. У діапазоні $\left(2,6^{\circ} \mathrm{C}-2,8^{\circ} \mathrm{C}\right)$ медіанне значення площі норми складає 0 \%, а для процесів патології 0,4 \% - 0,6 \% (p<0,05). Найбільш прогностичним $\epsilon$ показник площі для діапазону $\left(1,8^{\circ} \mathrm{C}-2,0^{\circ} \mathrm{C}\right)$ : для Н термограм медіанне значення склало 0,7 \%, для П процесів - 3,3 \% - 3,9 \% (p<0,05). При виборі оптимального порогу розділення за цим показником (П прогнозується при площі Delt(1,8$2,0)>1,6$ \%) чутливість та специфічність тесту сягають $74 \%$.

При аналізі показників узагальненої дисперсії розподілу поля температур виявлено суттєву відмінність показників для Н та П процесів (для всіх розмірів квадратів відмінність між групами статистично значима, p<0,001 за критерієм КрускалаУолліса). Показники для норми в середньому нижчі $(\mathrm{p}<0,05)$, ніж для патології. Однак чутливість та специфічність прогнозування ризику патологічного процесу при використанні цих показників не перевищували 65 \%. Тому цей фактор також не може бути використаний як єдина ознака для прогнозування ризику патології.

Кращі прогностичні характеристики при розділенні за термограмами Н та П процесів мали показники узагальненого стандартного відхилення поля асиметрії температур. ROC-аналіз (рис. 2) свідчить, що при виборі оптимального порогу розділення чутливість та специфічність прогнозування ризику патології за показниками узагальненого стандартного відхилення поля асиметрії температур досягають $72 \%$ - 74 \%, але й цей фактор не може бути використаний як єдина ознака для розділення Н та П процесів.

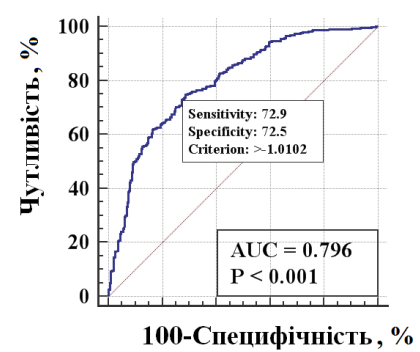

a)

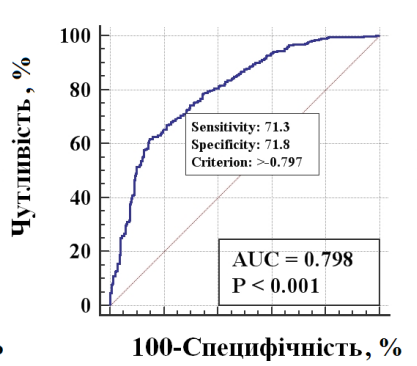

б)

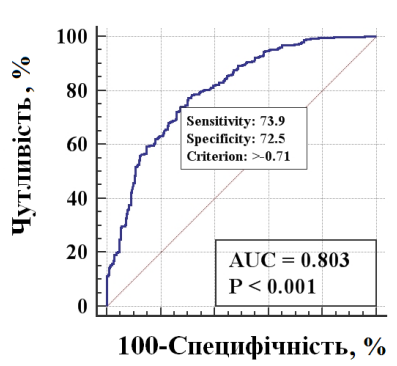

B)

Рис. 2. ROC-криві прогнозування ризику патології за показниками узагальненого стандартного відхилення поля асиметрії температур для квадратів розміром: 2х2 — a), 5x5 — б), 12х12 — в) 
Отже, до найбільш значимих показників, що описують поле температур М3, які дозволяють провести дискримінацію процесів Н та П, можуть бути віднесені: відносна площа підвищеної $\left(>3,0^{\circ} \mathrm{C}\right)$ відносно реперної температури M3 (чутливість та специфічність приблизно дорівнює 70 \%); відносна площа поля асиметрії температур, що не перевищує $0,2^{\circ} \mathrm{C}$ (чутливість та специфічність приблизно дорівнює 70 \%); відносна площа поля асиметрії температур у діапазоні $1,8^{\circ} \mathrm{C}-2,0^{\circ} \mathrm{C}$ (чутливість та специфічність приблизно дорівнює 74 \%); показники узагальненого стандартного відхилення поля асиметрії температур (чутливість та специфічність приблизно дорівнює 72 \% - 74 \%). Аналіз свідчить, що ефективне розділення Н та П процесів не може бути проведене за окремим показником характеристики термограми МЗ. Для побудови системи прогнозування ризику повинна бути використана багатофакторна модель.

Побудова автоматизованої експертної системи виявлення патології МЗ. Для побудови системи виявлення патології М3 усі 685 отриманих термограм поля температури за допомогою генератора псевдовипадкових чисел були поділені на три множини: 1) навчальну множину даних (train set), що використовується для «навчання» моделі (розрахунку коефіцієнтів моделі класифікації), - 421 приклад; 2) контрольну множину даних (verify test), що використовується для запобігання «перенавчанню» моделі (служить для припинення підгонки коефіцієнтів моделі навчальної множини), - 24 приклади; 3) підтверджуючу множину, що не використовується для підгонки коефіцієнтів моделі і служить тільки для перевірки її прогностичних якостей на нових даних, - 240 прикладів.

Модель класифікації будувалася окремо для поля термограм пацієнток до 40 років та 40 і більше років. Для оцінки можливості дискримінації Н та П процесів на показниках, що характеризують термограму, побудовано лінійну модель класифікації у два класи на всіх 68 факторних ознаках.

Отримана 68-факторна лінійна модель прогнозування - адекватна, площа під кривою операційних характеристик (AUC) $=0,84$ (95\% вірогідний інтервал (ВI) 0,82-0,87), статистично значимо відрізняється від $0,5(\mathrm{p}<0,001)$. Хороша узгодженість [23] факторних ознак із ризиком патології (AUC>0,8) свідчить про можливість використання показників для прогнозування ризику П процесу. В той же час слід відзначити, що оцінка ризику патології, навіть тільки за одною факторною ознакою (такою, як відносна площа асиметрії поля температур або показник узагальненого стандартного відхилення поля асиметрії температур) дає можливість досягти чутливості та специфічності $72 \%$ - 74 \%, AUC приблизно 0,80. Додавання іще 67 ознак лише трохи поліпшує прогностичні характеристики, досягнуті в однофакторній моделі. Разом з цим встановлений високий (>70 \%) відсоток хибнопозитивних результатів негативно позначиться при використанні такої моделі при скринінгу. Виявлені недоліки прогнозування ризику патології у лінійній 68-факторній моделі можуть бути пов'язані з високим рівнем взаємної кореляції факторних ознак, що обумовлює низьку ефективність покращення прогностичних характеристик при додаванні нових ознак та можливою нелінійною залежністю результуючої та факторних ознак, що не може бути враховано в рамках лінійної моделі.

Для урахування перелічених недоліків моделі прогнозування патології М3 та їх усунення задіяно метод виділення мінімального набору факторів із використанням нелінійних моделей прогнозування. Для вибору мінімального набору значимих ознак застосовано «генетичний алгоритм» відбору [26]. Це дозволило скоротити набір вхідних факторних ознак до 16 для моделі прогнозування ризику патології за термограмами пацієнток до 40 років та 18 ознак для моделі прогнозування ризику патології за термограмами пацієнток 40 років і старше. На виділених факторних ознаках побудовано лінійну систему прогнозування ризику патології M3 (проста система 3 лінійними функціями активації) та нелінійну систему прогнозування ризику патології (використано багатошаровий персептрон - MLP з одним прихованим шаром із сигмоїдними функціями активації). Після навчання лінійної та MLP систем оцінки ризику патології M3 визначені їх прогностичні характеристики (рис. 3). 


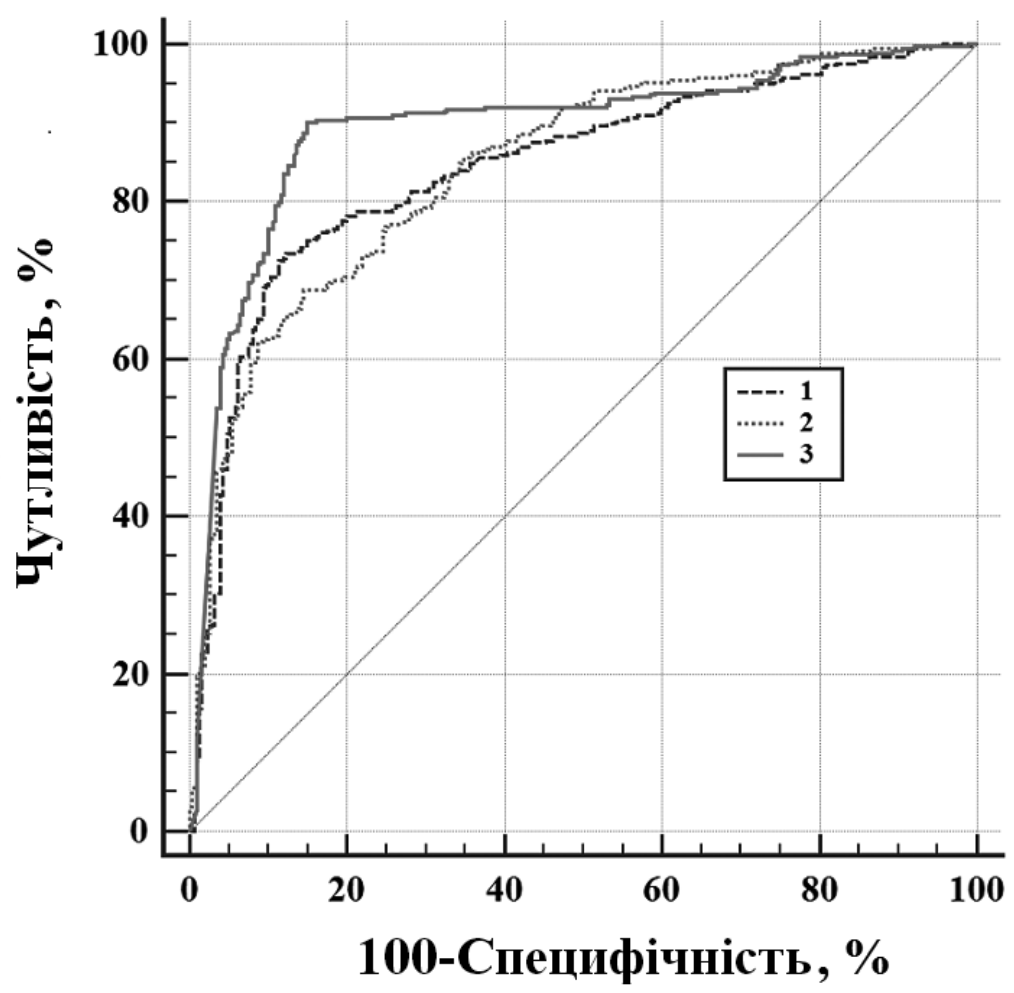

Рис. 3. ROC криві моделей прогнозування ризику патології М3: лінійна модель за 68-ма показниками (1), $\mathrm{AUC}_{1}=$ 0,84 (95 \% BI 0,82-0,87); лінійна модель за значимими показниками (2), AUC2 = 0,85 (95 \% BI 0,82-0,87); MLP модель за значимими показниками (3), AUC3 = 0,89 (95 \% BI 0,87-0,92)

Порівняння прогностичних якостей трьох моделей не виявило статистично значимих відмінностей площі під кривими операційних характеристик лінійної моделі за 68-ма ознаками та лінійної моделі за значимими ознаками $(\mathrm{p}=0,96)$. Це $є$ підтвердженням значимості саме цих ознак (16 для термограм пацієнток до 40 років та 18 для термограм пацієнток 40 років і старше) для розділення процесів Н та П. Прогностичність MLP моделі статистично значимо вище як прогностичності лінійної моделі за значимими ознаками $(\mathrm{p}=0,001)$, так і прогностичності лінійної моделі за 68-ма ознаками $(\mathrm{p}=0,006)$, що підтверджує значимість виділених факторних ознак та наявність нелінійності їх зв’язку з ризиком патології М3.

При виборі оптимального порогу тесту для лінійної моделі за значимими ознаками чутливість тесту склала 76,3 \% (95 \% ВI 71,7 \% - 80,5 \%); специфічність тесту - 75,4 \% (95 \% BI 70,2 \% - 80,1 \%); прогностичність позитивного значення $+\mathrm{PV}=25,6 \%$ (95 \% BI 22,0 \% - 29,7 \%) (розраховувалася із 10 \% розповсюдженості патології М3 при проведенні скринінгу); прогностичність негативного значення -PV = 96,6 \% (95 \% BI 95,9 \% - 97,2 \%) (розраховувалася із $10 \%$ розповсюдженості патології M3 при проведенні скринінгу). Для MLP моделі за значимими ознаками чутливість тесту 90,2 \% (95 \% BI 86,7 \% - 93,0 \%); специфічність тесту — 85,1 \% (95 \% ВI 80,6 \% - 88,9 \%); прогностичність позитивного значення +PV $=40,2 \%$ (95 \% ВI 34,0 \% - 46,8 \%) (розраховувалася із $10 \%$ розповсюдженостіпатології МЗприпроведенні скринінгу); прогностичність негативного значення-PV = 98,7\% (95 \% ВI 98,3 \% - 99,1 \%) (розраховувалася із 10 \% розповсюдженості патології МЗпри проведенні скринінгу).

Враховуючи перелічені обставини, в якості моделі прогнозування за аналізом термограм було вибрано нелінійну нейромережеву MLP модель. Схема аналізу термограми пацієнтки наведена на рис. 4. При проведенні аналізу ступеню впливу ознак на ризик наявності патології для моделі оцінки термограм пацієнток до 40 років встановлено, що у найбільшій мірі для цієї групи пацієнток патологія проявляється за показниками площі асиметрії температур для діапазонів невеликої асиметрії Delt $(<0,2)$ i Delt $(0,4-0,6)$ та великої асиметрії $\operatorname{Delt}(1,6-1,8)$ i $\operatorname{Delt}(1,8-2,0)$, а також показниками узагальненого стандартного відхилення поля температур лівої та правої МЗ для квадратів розміру 8x8 cm2 Rln_S8 L_ln_S8. 

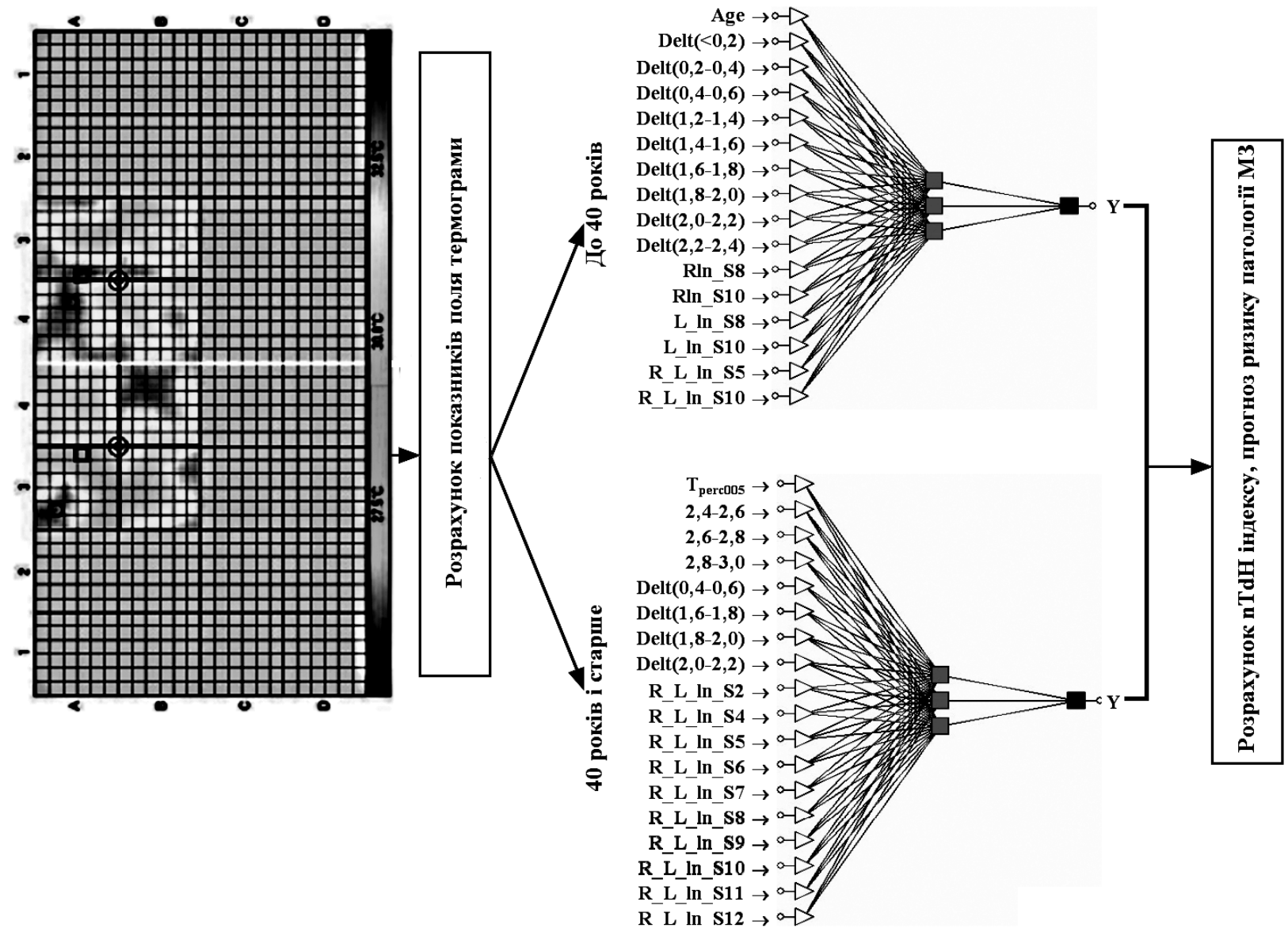

Рис. 4. Схема системи прогнозування ризику патології МЗ за аналізом термограм. Трикутниками позначені нейрони вхідного шару (лінійні функції активації), сірими квадратами — нейрони прихованого шару (сигмоїдні функції активації), чорними квадратами — нейрони вихідного шару (сигмоїдні функції активації)

У моделі оцінки термограм пацієнток 40 років і старше у найбільшій мірі патологія проявляється за показниками узагальненого стандартного відхилення асиметрії поля температур для квадратів різних розмірів R_L_ln_S2, R_L_ln_S6, R_L_ln_S9, R_L_ln_S12, R_L_ln_S8, R_L_ln_S7 та показниками площі асиметрії температур для діапазонів великої асиметрії Delt(1,8-2,0), Delt(2,0-2,2).

Висновки. Проведено порівняльний аналіз кількісних показників оцінки поля температур поверхні шкіри М3, отриманого при використанні контактної цифрової термографії, при нормі та патологічних процесах. Виділено набір показників, значимих для прогнозування патологічних процесів, на яких побудовано моделі прогнозування ризику патології М3.
Доведено, що нелінійна нейромережева MLP модель забезпечує найкращу здатність розділення норми та патології: чутливість тесту 90,2 \% (95 \% ВI 86,7 \% 93,0 \%); специфічність тесту 85,1 \% (95 \% ВІ 80,6 \% - 88,9 \%). Нейромережеву MLP модель реалізовано в комп’ютерній програмі «ExpertTdistrHurstExp.exe», на базі якої створено автоматизовану експертну систему оцінки термограм МЗ, що дозволяє проводити розмежування груп жінок при профогляді на групи з патологією та без патології М3.

Робота виконана при фінансовій підтримціі МОН України за держсавним замовленням на найважливіші науково-технічні (експериментальні) розробки та науково-технічну продукцію в 2018-2019 роках. 


\section{Література.}

1. Ng E. Y. A review of thermography as promising noninvasive detection modality for breast tumor. Int. J. Therm. Sci. 2009. 48 (5). Р. 849-859.

2. Ковальчук И. С., Дунаевский В. И., Венгер Е. Ф., Котовский В. И., Назарчук С. С. Возможности дистанционной инфракрасной термографии в диагностике заболеваний молочных желез (доброкачественные изменения). Укр. мед. часопис. 2013. № 3 (95). С. 165-169.

3. Приходченко В. В., Приходченко О. В., Белошенко В. А., Дорошев В. Д., Карначев А. С. Повышение эффективности отборочного этапа селективного скрининга заболеваний молочной железы. Медикосоціальні проблеми сім’ї. 2009. Т. 14, № 4. С. 20-25.

4. Приходченко В. В., Думанский Ю. В., Приходченко О. В., Белошенко В. А., Дорошев В. Д., Карначев А. С. Применение контактного цифрового термографа ТКЦ-1 в диагностике заболеваний молочных желез. Донецк, 2012. 189 с.

5. Кожевникова И. С., Панков М. Н., Ермошина Н. А. Методы обработки и анализа термограмм для экспресс-диагностики новообразований молочных желез. Журнал медико-биологических исследований. 2017. Т. 5, № 2. С. 56-66.

6. Кожевникова И. С., Панков М. Н., Грибанов А. В., Старцева Л. Ф., Ермошина Н. А. Применение инфракрасной термографии в современной медицине. Экология человека. 2017. № 2. С. 39-46.

7. Режим доступу: https://www.imcs-4u.com/procedury/ thermografiya.html.

8. Розенфельд Л. Г., Колотилов Н. Н. Дистанционная инфракрасная термография в онкологии. Онкология. 2001. T. 3, № 2-3. С. 103-106.

9. Маркель А. Л., Вайнер Б. Г. Инфракрасная термография в диагностике рака молочной железы (обзор зарубежной литературы). Терапевт. архив. 2005. Т. 776, № 10. С. 57-61.

10. Приходченко В. В., Приходченко О.В.Диагностика заболеваний молочной железы с помощью цифрового контактного термографа. Медико-соціальні проблеми сім’ї. 2005. Т. 10, № 3-4. С. 61-64.

11. Приходченко В. В., Приходченко О. В., Білошенко В. О., Карначов О. С., Дорошев В. Д., Калініна О. I. Можливості контактної цифрової термографії у ранній доклінічній діагностиці раку молочної залози. Онкологія. 2009. Т. 13, № 2. С. 125-129.

12. Венгер Є. Ф., Гордієнко В. І., Дунаєвський В. І., Котовський В. Й., Маслов В. П. Застосування термографії в Україні. Наука та інновації. 2015. Т. 11, № 6. C. 5-15.

13. Etehadtavakol M., Ng E. Y. K. Breast thermography as a potential non-contact method in the early detection of cancer: A review. J. Mech. Med. Biol. 2013. 13(2). Art. № 1330001.

14. Белошенко В. А., Дорошев В. Д., Карначев А. С., Приходченко В. В. Комплекс аппаратуры для ранней диагностики онкологических заболеваний методом контактной цифровой термографии. Наука та інновації. 2007. Т. 3, № 5. С. 11-25.

15. Bubnov R. V., Melnyk I. M. The methods of fractal analysis of diagnostic images. Initial clinical experience. Lik Sprava. 2011. № 3-4. P. 108-113.

16. Bubnov R. V., Melnyk I. M. Hepatic oncology diagnosis based on imaging fractal analysis: preliminary results. EPMA Journal. 2014. 5. A43. Режим доступу: https:// link.springer.com/article/10.1186\%2F1878-5085-5S1-A43.

17. Etehadtavakol M., Lucas C., Sadri S., Ng E. Y. K. Analysis of breast thermography using fractal dimension to establish possible difference between malignant and benign patterns. J. Healthcare Eng. 2010. Vol. 1, № 1. P. 27-43.

18. Baish J. W., Jain R. K. Fractals and cancer. Cancer Res. 2000. Vol. 60. P. 3683-3688.

19. Ramirez-Cobo P., Vidakovic B. A 2D wavelet-based multiscale approach with applications to the analysis of digital mammograms. Computational Statistics and Data Analysis. 2013. Vol. 58, № 2. P. 71-81.

20. Dumansky Y. V., Lyakh Y. E., Gorshkov O. G., Gurianov V. G., Prihodchenko V. V. Fractal dimensionality analysis of normal and cancerous mammary gland thermograms. Chaos, Solitons and Fractals. 2012. Vol. 45. P. 1494-1500.

21. Carbone A. Algorithm to estimate the Hurst exponent of highdimensional fractals. Phys. Rev. E. 2007. Vol. 76. P. 056703.

22. Petrie A., Sabin C. Medical Statistics at a Glance. 2nd ed. Blackwell Publishing. 2005.

23. Посібник з біостатистики. Аналіз результатів медичних досліджень у пакеті EZR (R-statistics) / В. Г. Гур’янов, Ю. Є. Лях, В. Д. Парій, О.В.Короткий, О. В. Чалий, К. О. Чалий, Я. В. Цехмістер: Навчальний посібник. К.: Вістка, 2018. 208 с.

24. Kanda Y. Investigation of the freely available easy-touse software 'EZR' for medical statistics. Bone Marrow Transplant. 2013. Vol. 48. P. 452-458.

25. Haykin S. Neural Networks: A Comprehensive Foundation. 2nd ed. - Prentice-Hall, Englewood Cliffs, NJ, 1999.

26. Лях Ю. Е., Гурьянов В. Г. Математическое моделирование при решении задач классификации в биомедицине. Український журнал телемедицини та медичної телематики. 2012. 2 (10). С. 69-76.

\section{References.}

1. Ng, E. Y. (2009). A review of thermography as promising non-invasive detection modality for breast tumor. Int. J. Therm. Sci., 48(5), 849-859.

2. Koval'chuk, I. S., Dunayevskiy, V. I., Venger, Ye. F., Kotovskiy, V. I., Nazarchuk, S. S. (2013). Vozmozhnosti distantsionnoy infrakrasnoy termografii v diagnostike zabolevaniy molochnykh zhelez (dobrokachestvennyye 
izmeneniya) [Possibilities of remote infrared thermography in the diagnosis of diseases of the mammary glands (benign changes)]. Ukr. med. Chasopis, 3(95), 165-169. [in Russian].

3. Prikhodchenko, V. V., Prikhodchenko, O. V., Beloshenko, V. A., Doroshev, V. D., Karnachev, A. S. (2009). Povysheniye effektivnosti otborochnogo etapa selektivnogo skrininga zabolevaniy molochnoy zhelezy [Improving the effectiveness of the screening stage for selective screening of breast diseases]. Medyko-sotsialni problemy simi, Vol. 14, 4, 20-25 [in Russian].

4. Prikhodchenko, V. V., Dumanskiy, Yu. V., Prikhodchenko, O. V., Beloshenko, V. A., Doroshev, V. D., Karnachev, A. S. (2012). Primeneniye kontaktnogo tsifrovogo termografa TKTS-1 v diagnostike zabolevaniy molochnykh zhelez [The use of contact digital thermograph TKTS-1 in the diagnosis of diseases of the mammary glands]. Donetsk, 189. [in Russian].

5. Kozhevnikova, I. S., Pankov, M. N., Ermoshina, N. A. (2017). Metodyi obrabotki i analiza termogramm dlya ekspress-diagnostiki novoobrazovaniy molochnyih zhelez [Methods of processing and analysis of thermograms for the rapid diagnosis of breast tumors]. Zhurnal mediko-biologicheskih issledovaniy, Vol. 5, 2, 56-66. [in Russian].

6. Kozhevnikova, I. S., Pankov, M. N., Gribanov, A. V., Startseva, L. F., Ermoshina, N. A. (2017). Primenenie infrakrasnoy termografii v sovremennoy meditsine [The use of infrared thermography in modern medicine]. Ekologiya cheloveka, 2, 39-46. [in Russian].

7. URL: https://www.imcs-4u.com/procedury/ thermografiya.html.

8. Rozenfel'd, L. G., Kolotilov, N. N. (2001). Distantsionnaya infrakrasnaya termografiya v onkologii [Remote infrared thermography in oncology]. Onkologiya, Vol. 3, 2-3, 103-106. [in Russian].

9. Markel', A. L., Vayner, B. G. (2005). Infrakrasnaya termografiya $\mathrm{v}$ diagnostike raka molochnoy zhelezy (obzor zarubezhnoy literatury) [Infrared thermography in the diagnosis of breast cancer (review of foreign literature)]. Terapevt. Arkhiv, Vol. 776, 57-61. [in Russian].

10. Prikhodchenko, V. V., Prikhodchenko, O. V. (2005). Diagnostika zabolevaniy molochnoy zhelezy s pomoshch'yu tsifrovogo kontaktnogo termografa [Diagnosis of breast disease using a digital contact thermograph]. Medyko-sotsialni problemy simi, Vol. 10, 3-4, 61-64. [in Russian].

11. Prykhodchenko, V. V., Prykhodchenko, O. V., Biloshenko, V. O., Karnachov, O. S., Doroshev, V. D., Kalinina, O. I. (2009). Mozhlyvosti kontaktnoyi tsyfrovoyi termohrafiyi u ranniy doklinichniy diahnostytsi raku molochnoyi zalozy [Possibilities of contact digital thermography in the early preclinical diagnosis of breast cancer]. Onkolohiya, Vol. 13, 2, 125-129. [in Ukranian].
12. Venger, E. F., Gordienko, V. I., Dunaevskiy, V. I., Kotovskiy, V. Y., Maslov, V. P. (2015). Zastosuvannya termografii v Ukraini [Application of thermography in Ukraine]. Nauka ta Innovatsii, Vol. 11, 6. 5-15. [in Ukranian].

13. Etehadtavakol, M., Ng, E. Y. K. (2013). Breast thermography as a potential non-contact method in the early detection of cancer: A review. J. Mech. Med. Biol., 13(2), Art. № 1330001.

14. Beloshenko, V. A., Doroshev, V. D., Karnachev, A. S., Prikhodchenko, V. V. (2007). Kompleks apparatury dlya ranney diagnostiki onkologicheskikh zabolevaniy metodom kontaktnoy tsifrovoy termografii [Complex of equipment for early diagnosis of oncological diseases by the method of contact digital thermography]. Nauka ta innovatsii, Vol. 3, 5, 11-25. [in Russian].

15. Bubnov, R. V., Melnyk, I. M. (2011). The methods of fractal analysis of diagnostic images. Initial clinical experience. Lik. Sprava, 3-4, 108-113.

16. Bubnov, R. V., Melnyk, I. M. (2014). Hepatic oncology diagnosis based on imaging fractal analysis: preliminary results. EPMA Journal, 5, A43. URL: https://link. springer.com/article/10.1186\%2F1878-5085-5-S1-A43.

17. Etehadtavakol, M., Lucas, C., Sadri, S., Ng, E. Y. K. (2010). Analysis of breast thermography using fractal dimension to establish possible difference between malignant and benign patterns. J. Healthcare Eng., Vol. 1, 1, 27-43.

18. Baish, J. W., Jain, R. K. (2000). Fractals and cancer. Cancer Res., Vol. 60, 3683-3688.

19. Ramirez-Cobo, P., Vidakovic, B. (2013). A 2D wavelet-based multiscale approach with applications to the analysis of digital mammograms. Computational Statistics and Data Analysis, Vol. 58, 2, 71-81.

20. Dumansky, Y. V., Lyakh, Yu. Ye., Gorshkov, O. G., Gurianov, V. G., Prihodchenko, V. V. (2012). Fractal dimensionality analysis of normal and cancerous mammary gland thermograms. Chaos, Solitons and Fractals, Vol. 45, 1494-1500.

21. Carbone, A. (2007). Algorithm to estimate the Hurst exponent of highdimensional fractals. Phys. Rev. E., Vol. 76, 056703.

22. Petrie, A., Sabin, C. (2005). Medical Statistics at a Glance. 2nd ed. Blackwell Publishing.

23. Gur'yanov, V. G., Lyah, Yu. Ye., Pariy, V. D. et al. (2018). Posibnik z biostatistiki. Analiz rezultativ medichnih doslidzhen u paketi EZR (R-statistics) [Biostatistics guide. Analysis of the results of medical research in the package EZR (R-statistics)]. Navchalniy posibnik. K.: Vistka, 208. [in Ukranian].

24. Kanda, Y. (2013). Investigation of the freely available easy-to-use software 'EZR' for medical statistics. Bone Marrow Transplant, Vol. 48, 452-458.

25. Haykin, S. (1999). Neural Networks: A Comprehensive Foundation. 2nd ed. - Prentice-Hall, Englewood Cliffs, NJ. 
26. Lyakh, Yu. Ye., Hur'yanov V. H. (2012). Matematycheskoe modelyrovanye pry reshenyy zadach klassyfykatsyy v byomedytsyne [Mathematical modeling for solving classification problems in biomedicine]. Ukrayins'kyy zhurnal telemedytsyny ta medychnoyi telematyky, 2(10), 69-76 [in Russian]. 